\title{
STUDENTS' ATTITUDE TOWARD “QUIPPER SCHOOL” AS AN ENGLISH ONLINE LEARNING MEDIA AT SMAN 1 ARGAMAKMURBENGKULU UTARA
}

\author{
Lusynta Febrianti \\ University of Bengkulu \\ lusyntafebrianti@gmail.com \\ Mulyadi \\ University of Bengkulu \\ ladunimulyadi@gmail.com \\ Gita Mutiara Hati \\ University of Bengkulu \\ gitawitanto@gmail.com
}

\begin{abstract}
This study aimed to find out students' attitude toward "Quipper School" as an English online learning media. The population of this research was the whole students of SMAN 1 Argamakmur Bengkulu Utara, with the total population 667 students. The sample of this research was 158 students. It was chosen by using clustered random sampling. The instrument that was used in this research was questionnaire which consists of 27 items and was divided into three aspect, namely cognitive, affective, and behavior aspect. Interview was used to confirm and to support the data from questionnaire. The result of this research showes that students had positive attitude toward "Quipper School" as an English online learning media, with the mean score for all aspect was 3.76; the mean score for cognitive aspect was 3.85; the mean score for affective aspect was 3.71; and the mean score for behavior aspect was 3.72. It means that students of SMAN 1 Argamakmur Bengkulu Utara generally have positive attitude toward "Quipper School" as an English online learning media.
\end{abstract}

Key words: Students' attitude, Quipper School 


\section{INTRODUCTION}

Learning a language is a process that people do consciously in order to master a particular language. In Indonesia, English is one of the foreign languages that most of people have to learn. People have already learned English starting from Elementary School, some of them even have learned it sincethey are in playgroup. However, not all of school institutions could execute English language learning process effectively and efficiently. The success of English learning process depends on some factors. Besides teaching technique and method that used by the teacher, media is also one of the factors which can make English learning process effective and efficient.

Media is really needed to make the English learning process run as well as possible. Learning media is a tool or device which makes the learning process become effective. Transferring the knowledge and information between teacher and student will be easier by using the media. KUO (1991) states that media is called educational media when the media transfers message in teaching and learning process. She adds that the use of media is very important in teaching and learning process, and it is impossible to coordinate teaching without using media.According to Gagne' and Briggs in Arsyad (2013) learning media is physical means that used to deliver learning materials such as book, tape recorder, cassette, video, film, graphic, picture, television, and computer. In other words, media is all of components or devices as learning sources in order to make students understand the materials which given by the teacher. By using the media, the learning process will be effective and efficient. It also makes students pay more attention to the learning process.

Besides media, there are also some factors from students themselves which help their English learning process successful.
Students must have high motivation when they learn English, so their motivation will force them to learn English as well as possible. Attitude of students is also an important factor in order to make the English learning process effective and efficient. Students' also must have positive attitude toward learning process itself, so they will give good responses to make the process succeeded.

Students' attitude is one of the most important thing when they learn language especially English as a foreign language. It is one of the important factors to make learning English is success. Students' attitude affects their level of learning English. It can give them bad or good impact. Gerungan (2010) stated that attitude is someone's view and feeling toward an object which followed by reaction based on his attitude toward an object itself. It emphasizes that students' reaction toward a particular thing or situation is based on their point of view or mind and feeling. Students' mind and feeling has important role in order to determine their actions. According to Allport in Sears (1998), attitude is a mental readiness and organized condition through experience influence toward responses of someone to the objects and situation connected to him. In other words, attitude is how students think, feel and behave toward a particular thing or situation.

On the other hand, Taylor et al (2009) states that attitude is the response disposition which contain affective, behavioral, and cognitive component. Affective component is someone's feelings related to the attitude. It consists of emotion or feeling of someone toward an object of attitude. Then, behavioral component is a tendency of someone to react toward an object attitude. It is about how people react in order to respond to a particular thing or situation. However, cognitive component is belief, 
knowledge of someone, and fact about an object of attitude.

Media and attitude are interrelated factors. Those factors cannot be separated in English learning process. Teacher should be more considerate about students' attitude toward various aspects included in learning process. Using media is good choice to make them into positive attitude. By using media, it can make a good learning process for students, so their attitude may be positive. If attitude of students toward media is positive, it makes the learning process become more effective and efficient. Students can understand the material which given by the teacher if the learning process effective and efficient. So, attitude of students is really important in order to make the English learning successful. Media can also make students become more active in the learning process.

Quipper School is one of the media that can be used in learning process. It is an online learning media for students. It does not only help students, but also helps teachers to teach their students wherever they are. Teacher can provide the material and exercise on Quipper School, so that students can access and learn at home by themselves. Sometimes, they use Quipper School for examination in the school. It is more efficient and effective, because it has no time limitation. On Quipper School, there are two portals, first is for teacher and second is for students. For teacher, it helps them in providing the material and giving exercise for students. Portal for students helps them to learn and to do exercises that are given by teachers, so it will be easier for them when they learn at home. The mark of students will be inputted in teacher's portal automatically.

SMAN 1 Argamakmur Bengkulu Utara is chosen for this research because it is the only one school found in Bengkulu that applies Quipper School as students' online learning media. It has already applied K13 where it requires that media have to include in learning process and emphasizes students should be more active than teacher. It is better if students use more media in their learning process. Hence, teacher asks students to use various media, starting from usual media such as projector to online media such as Quipper School in English learning process. Students of SMAN 1 will be population of this research because they have been using Quipper School as their English online learning media. They are $1^{\text {st }}$, $2^{\text {nd }}$, and $3^{\text {rd }}$ grade students. They use Quipper School since they are at first grade in Senior High School. It is new media, and it gives new atmosphere for them. So, it is important to know their attitudes towards Quipper School itself. By knowing their attitude, we are as a teacher can know their response toward media that is new for them.

Some previous studies are needed in order to find the gap between those studies. There were previous studies that related to this research about students' attitude. First, Styaningrum(2013) conducted a research entitled "Students' Attitude toward Learning English in SDN Sumogawe 04". The researcher wanted to analyze how elementary school students' attitude toward learning English. The result of this research is most of students have positive attitude toward learning English. Second, Rochmah (2015) also conducted the research about students' attitude. The title of her research is "An Analysis of Students' Attitude toward the Teaching of English Subject at SMK Negeri in Kota Bengkulu Academic Year 2014/2015". The result of this research shows that students have positive attitude toward the teaching English subject.

Based on the previous studies above, it was found that they were focused on learning English in general. Both of them investigate the same object of attitude. In this research, the researcher wants to focus 
on other object of attitude that is media in English learning. It is more specific object of attitude. Not only the usual media, but the researcher wants to focus on online media.

Based on the explanation above, the researcher wanted to conduct the research entitle "Students' Attitude toward "Quipper School" as an English Online Learning Media at SMAN 1 Argamakmur Bengkulu Utara Academic Year 2016/2017.

\section{METHOD}

Method that used in this research was descriptive mixed method. The descriptive method is useful for investigating a variety of educational problem (Gay L.R: 1990).The population of this research was students of SMAN 1 Argamakmur Bengkulu Utara. They are $1^{\text {st }}, 2^{\text {nd }}$, and $3^{\text {rd }}$ grade students of SMAN 1 Argamakmur Bengkulu Utara which use Quipper School as their English online learning media. It consisted of 3 programs. There were 10 classes of $1^{\text {st }}$ grade, 10 classes of $2^{\text {nd }}$ grade, and 10 classes of $3^{\text {rd }}$ grade; they were 6 MIPA classes, 3 social classes, and 1 language class. Total of population were 667 students.

Purposive sampling was used for this research. According to Sugiyono (2011) the purposive sampling is the technique sampling that is used for particular consideration. The researcher took 2 classes from each grade by recommendation of the English teacher, so there were 6 classes will be sample for this research. The classes who become sample were science classes because the numbers of science classes are dominant. So, it was recommended for the sample of the research to science group. It was chosen in order to maintain of representativeness for the random sampling.

The instrument that was used in this research was a questionnaire. It was developed based on Revised Bloom's Taxonomy. A 27-items questionnaire was used to guide the researcher to find out the data of students' attitude toward Quipper School as their English online media. There were three components which were included in the questionnaire; they were cognitive, affective and behavior aspect. Based on Revised Bloom's Taxonomy, there were 6 categories for cognitive aspect, 5 categories for affective aspect, and 7 categories for behavior aspect. But, there were only some categories were used in the questionnaire. The researcher only chose the categories which suitable with the condition of using "Quipper School" as an English online learning media. Interview was needed for completing, supporting and confirming the data of questionnaire.The interview consisted of some questions related to the students' attitude toward Quipper School. It could be from the questionnaire or other questions which supported the confirmation of the data from questionnaire.

There were some steps for analyzing the data. First, after the data was arranged, the mean score of each student and whole students were coutedby using the formula (Sudjana, 2005) below:

Where:

$$
\mathbf{X}=\frac{\sum X i}{N}
$$

$\mathrm{X}=$ Mean score of students' attitude

$\sum X i=$ Total score of respondent (for each student) / total mean score of sample (for whole of questionnaire)

$\mathrm{N}=$ Total numbers of items (for each student) / total numbers of sample (for whole of questionnaire)

After that, the interval of the students' mean score was found in order to make the classification of students' attitude. The researcher found the interval of each student and whole students' mean score by using Hamburg formula in Rochmah (2015):

$$
\mathbf{I}=\frac{\boldsymbol{H}-\boldsymbol{L}}{\boldsymbol{K}}
$$


Where:

$\mathrm{I}=$ Size of class interval

$\mathrm{H}=$ The value of highest score

$\mathrm{L}=$ The value of lowest score

$\mathrm{K}=$ The total of classification

After that, the classification was made based on the interval of students' mean score. The following table is the classification of students' attitude by using Hamburg formula in Rochmah (2015) to find the interval, and Likert scale for the predicate:

Table 1.Attitude Category

\begin{tabular}{|c|c|}
\hline Classification & Predicate \\
\hline $4,21-5,00$ & Very Positive \\
\hline $3,41-4,20$ & Positive \\
\hline $2,61-3,40$ & Neutral \\
\hline $1,81-2,60$ & Negative \\
\hline $1,00-1,80$ & Very Negative \\
\hline
\end{tabular}

In order to know the percentage, the researcher used the proportion formula (Sudjana, 2005). The formula as follows:

Where:

$$
P=\frac{F}{N} \times 100 \%
$$

$\mathrm{P}=$ Percentage of the data

$\mathrm{F}=$ Frequency of the data

$\mathrm{N}=$ Total numbers of the sample

\section{RESULT AND DISCUSSION}

The result showed that students had positive attitude toward "Quipper School" as an English online media on each aspect; cognitive, affective, and behavior aspect. It can be seen from mean score of students in each aspect. The mean score of each aspect had over 3.7. The result of the score can be seen on the following table:

Table 2.Mean Score of Attitude Aspect

\begin{tabular}{ccc}
\hline Aspect & Total Score & Mean Score \\
\hline Cognitive & 6084 & 3.85 \\
Affective & 6456 & 3.71 \\
Behavior & 3509 & 3.72 \\
\hline
\end{tabular}

Generally, students had positive attitude toward "Quipper School" as an
English online learning media. There is a similar result of previous study with this research. Eren (2012) that conducted the research entitle "Students' Attitude towards Using Social Networking in Foreign Language Classes: A Facebook Example". He wanted to analyze students' attitude at Gaziantep Turkey towards the using social networking (facebook) in the classroom. The result showed that students were having very positive towards using facebook in the classroom. Based on the result of those studies, it showed that students have positive attitude toward media that use in teaching learning process, especially online media. Media is called educational media when the media transfers message in the teaching learning process (KUO, 1991). By using media, teaching learning process becomes more effective and efficient. It helps the transferring knowledge between students and teacher become easier.

\section{CONCLUSION}

Based on the result and discussion, it can be concluded that students' attitude toward "Quipper School" as an English online learning media was positive. The respondents in this research are 6 classes from each grade. Students had positive attitude toward Quipper School on each aspect. There were 3 aspect in this research, they were cognitive, affective, and behavior aspect. The highest mean score for each aspect is cognitive aspect. The lowest mean score is for affective aspect. However, in general, students' attitude for those aspects is positive.

Based on the result and discussion, there are some suggestion for English teacher and further researchers: First, it is better to make the English learning process become interesting by including the media (other creative media) in the process of learning English. In addition, teacher should motivate the students who has negative 
attitude, and give more attention to students, so English learning process become effective and efficient.

Second, it is suggested to do the research with different object; it does not to find the students' attitude, but to investigate the implementation of using the media (e.g. Quipper School) in the learning process. On the other hand, further researcher also can conduct the research about the correlation between students' attitude and their achievement.

\section{REFERENCES}

Pembelajaran.Depok:

RajaGrafindoPersada.

Eren, O. (2012). Students' Attitude towards Using Social Networking in Foreign Language Classes: A Facebook Example. International Journal of Business and Social Science, Vol. 3 No. 20.

Gay, L.R. (1990). Educational Research (Competencies for Analysis and Application).Florida: International University.

Gerungan,

W.A.

(2010).

PsikologiSosial.Bandung:

RefikaAditama.

KUO, Christine. (1991). The Importance of Educational Media in Teaching.Buletin of Social Education, volume 2.

Rochmah, D. (2015). An Analysis Students' Attitude toward the Teaching of English Subject at SMK Negeri in Kota Bengkulu Academic Year 2014/2015. Bengkulu: Unpublished S1 Thesis of FKIP UNIB.

Sears, D.O., Freedman, J.L., \&Peplau, L.A., (2001). PsikologiSosial(5 ${ }^{\text {th }}$ Ed.). Jakarta: Erlangga.

Styaningrum, D. (2001). Students' Attitude toward Learning English in SDN Sumogawe 04. Salatiga: Thesis of
FKIP SatyaWacana Christian University.

Sudjana,.(2005). Metodastatistika.Bandung: PT. Tarsito.

Sugiyono.

(2011).

MetodePenelitianKuantitatif,

Kualitatifdan $R \quad \& \quad D$. Bandung: Alfabeta.

Taylor, Shelley E., et al. (2009). PsikologiSosial.Jakarta: Kencana. 